\title{
The interplay of global governance with domestic and local access: Insights from the FLEGT VPAs in Ghana and Indonesia
}

\author{
Authors: Constance L. McDermotta ${ }^{\mathrm{a}}$ Mark Hirons ${ }^{\mathrm{b}}$ and Abidah Setyowati ${ }^{\mathrm{c}}$
}

Keywords: access, governance, law, globalization, timber, trade

\begin{abstract}
This paper examines the EU FLEGT Voluntary Partnership Agreements (VPAs) with Ghana and Indonesia to explore how scale and sources of authority shape access to forest resources. VPAs require the development of internationally recognized legality verification systems to eliminate trade in illegal wood, and thus aim to reinforce state law while opening it to broader national and international scrutiny. Analysis of relevant documents, combined with over 70 stakeholder interviews at local to international scales, reveal significant differences between Ghana and Indonesia in the design of their verification systems, and the attention given to local and domestic forest access. Yet in both countries, a strong focus on legality verification, coupled with a lack of key governance reforms, favours international trade over local access. This calls into question the EU's growing legality agenda and highlights the need for alternative, more equitable, approaches to reforming domestic resource governance.
\end{abstract}

Author affiliations: a) Senior Fellow, Environmental Change Institute, University of Oxford; b) Departmental lecturer and MSc Course Director, Environmental Change Institute, University of Oxford; c) Research Fellow, School of Regulation and Global Governance, Australian National University. 


\section{Introduction}

This paper examines the EU Forest Law Enforcement, Governance and Trade (FLEGT) initiative to understand how scale and sources of authority shape access to forest resources. Following on Ribot and Peluso (2003: 153), we view access as involving a diverse array of means, relations and processes which shape people's "ability to derive benefits from things". While the dynamics of access are complex and context-specific, we consider whether the international scale of FLEGT, and its reliance on state-based, inter-governmental and market-based authority, serve as overarching factors that determine access. We select two contrasting cases of FLEGT Voluntary Partnership Agreements (VPAs) in Ghana and Indonesia, to identify levels of similarity and difference across country contexts.

FLEGT emerged as part of a broad and growing complex of international initiatives aimed at stemming tropical forests loss (e.g. Humphreys 2006). Underlying these initiatives, is the implicit understanding that forest loss is a global concern, driven in part by international trade (e.g. Hosonuma et al 2012) and linked to global challenges such as climate change and biodiversity loss (e.g. Bonan 2008; Gibson et al. 2011). This global framing, in turn, lends legitimacy to international authority (McDermott et al 2011), and favors strategies which enable external control over local actors and resources (Scott 1998).

Prior to FLEGT, efforts to assert international control over forests have met with strong resistance among state, industry and civil society actors. For example, proposals to establish a UN forest convention were resisted by state actors who argued that a convention would violate their sovereign right to govern forests, and by NGOs who feared a convention would favour industrial extraction over forest conservation (Humphreys 2006). NGOs and the private sector 
then developed forest certification as a form of non-state and market-driven governance (Cashore, Auld, and Newsom 2004). Forest certification was legitimized by the use of multistakeholder processes to develop voluntary standards of good forest practice, coupled with 'independent' and 'objective' auditing systems to verify compliance with those standards (McDermott 2012). However conflict over the relative roles of civil society, state and industry in setting forest standards has led to a proliferation of competing certification schemes. At the same time, limited market demand for certified products has constrained the spread of certification, particularly in the global South (e.g. Auld, Gulbrandsen, and McDermott 2008, Ebeling and Yasué 2009).

FLEGT could be seen as a response to the above pitfalls of international forest governance. Firstly, FLEGT's core aim is to eradicate the import of 'illegal' wood into EU countries (EC 2003). By focusing on legality, FLEGT would appear to reinforce, rather than undermine, state authority to define acceptable forest practice (e.g. Bartley 2014). Secondly state governments, unlike voluntary certification schemes, hold the sovereign right to enforce legal compliance across their entire jurisdiction and hence to achieve large-scale impact (e.g. Cashore and Stone 2012). Thirdly, the EU's FLEGT initiative is firmly rooted in trade - while international norms of sovereignty at least notionally constrain the EU from interfering in the internal affairs of nonEU countries, the EU can apply indirect influence through the regulation of its own markets. Finally, while NGOs and the forest industry are in conflict over certification (Cashore, Auld and Newsom 2004), their interests in illegal logging are potentially complementary. Forest activists view FLEGT as a tool to promote 'good governance' and forest conservation more generally (e.g. FERN 2018), while high capacity international industry actors could benefit from eradicating price competition from unregulated logging (e.g. Seneca et al. 2004: 7). 
While a focus on legality offers various strategic advantages to international and state actors, it faces its own challenges of authority and legitimacy. It is widely known that state capacity is limited in many developing country forests, and associated with problems of corruption, contradictory legal frameworks, etc. Furthermore, legality is not necessarily synonymous with environmental protection or community benefit (e.g. Colchester 2006). The FLEGT Action Plan therefore also articulates the aims of 'promoting equitable and just solutions...that do not have adverse impacts on poor people' and that contribute to 'good governance' and 'sustainable environmental management' (EC 2003).

In recognition of these multiple aims, a core mechanism for realizing the FLEGT Action Plan has been the development of "Voluntary Partnership Agreements" (VPAs) with developing countries. VPAs are negotiated through multi-stakeholder processes as a means to gain legitimacy and to support appropriate legal reforms. Similar to forest certification, VPA multistakeholder processes involve the development of a licensing system which is based on the establishment of a legality standard and the creation of an 'objective' and externally verifiable process for ensuring the legality of wood products. Once the system is operational, only licensed wood is allowed into the EU. In this way, FLEGT draws on market-based authority by providing market incentives for legal compliance, as well as international and state-based authority through its focus on legal compliance, international scrutiny and the regulation of international trade. Indonesia and Ghana, our focal countries, were among the first countries to sign a FLEGT VPA, and have since advanced the furthest in VPA implementation. Hence they illustrate how the assertion of international, state and market-based authority through VPA processes has worked in practice, and with what impacts on forest access. 
The next section lays out the theoretical and analytical framework guiding the rest of the paper. This is followed by a description of the methods used to conduct the research. We then proceed to the analysis of legality, the VPA and forest access in Ghana and Indonesia, followed by a final summary and conclusions.

\section{Theoretical framework}

This paper draws on Ribot and Peluso (2003), by adopting a broadly conceptualized view of 'access' as referring to 'the ability to benefit from things'. This ability is embedded in a 'bundle of powers' that include not only state-based or traditionally sanctioned 'rights' of access, but also 'structural and relational factors' including market structures, relations of authority and legitimacy and the production of knowledge and discourse. As will be clear in our VPA countrylevel analyses, these factors are intertwined. For example authority, as in the power and ability to control access, can be gained or enhanced through market forces, and may acquire 'legitimacy', as in social acceptance as just or appropriate, through support from NGOs or other trusted actors. Legitimacy, in turn, is a key source of authoritative power, in that it facilitates social cooperation and reduces the need for direct control and coercion (e.g. Bodansky 1999).

In regards to 'rights', Ribot and Peluso (2003) highlight a plurality of ways in which these may be created, maintained and controlled. These include formal property rights recognized by the state, including rights to land and/or rights to harvest forest resources. States typically define land ownership through legal mechanisms such as land titles and deeds, and control access to resources through formal mechanisms such as permits and licenses. However, even these formal 'codified' rights must be actively exercised and negotiated. The 'legitimacy', i.e. the perceived social appropriateness and hence buy-in of these legal claims, may vary according to actors and 
across scales. There may be conflicting legislation and conflicting interpretations among different state departments and at national and sub-national scales. Frequently customary or conventional access rights also exist, again with varying levels of recognition and legitimacy among social actors. The phrase 'legal pluralism' has been used to refer to this often complex, overlapping landscape of rights (e.g. Tamanaha 2008).

While the Ribot and Peluso 'theory of access' (2003) reveals many more avenues for actor agency than would be evident from laws and property rights alone, it offers no general hypotheses for explaining when and why one might expect dynamics of access to play out in a particular way in a particular context. As discussed above, we hypothesize two critical factors, scale and source of authority, as providing explanatory power in the context of international forest governance.

In regards to scale, Scott in his seminal work 'Seeing Like a State' (1998), has observed how state and colonial governments over the course of centuries have attempted to consolidate control over their populations, territories and resources through a process of simplification and standardization, e.g. through registries, cadastral surveys, and codified laws. These standardized systems make certain attributes of local actors 'legible' from a distance and at scale, while rendering others invisible or illegitimate.

These trends have gained further force in the twentieth century, with the standardization of global trade and the emergence of the International Organization for Standardization (ISO), a meta-standards organization which sets global standards for standard-setting and 'third party' 'independent' auditing of performance (Mutersbaugh 2005). ISO and the standards-making systems that abide by its rules, make claims to universal or global legitimacy based on principles 
of objectivity, science and reason, and the apparent dis-embedding of decision-making from social relations and social context (Giddens 1990).

National bureaucracies and international standards systems such as ISO that are designed to create legibility for distant actors involve their own complexities and specialized knowledge systems which are illegible to many local-scale actors. Legitimacy at the local level, in contrast, is frequently embedded in inter-personal and community-based relationships and intimate knowledge of the local landscape (Scott 1998). Hence in the analysis of governance in a multiscale context it is important to consider not only who are the actors that drive that process, but at what scale they operate, in order to understand why certain laws, structures and mechanisms may be favoured over others.

(McDermott et al. 2011) identify three major sources of authority commonly exercised in international forest governance initiatives, including state-based, market-based and donor-based authority. In the context of FLEGT, EU states hold sovereign authority which they can use to regulate the entry of goods into EU markets; they also hold donor authority to dictate the actions required to receive donor funds. The EU is also as a large consumer of high value tropical wood products, which lends it market-based authority. The legitimacy of all of these EU's authorities, at the same time, is firmly rooted in the state-based authority of VPA partner countries to enforce their own laws. In addition, NGOs may assert their moral authority to influence market demand, or to pressure governments and industry within the EU or partner countries (Bernstein and Cashore 2000). As hypothesized by (Lesniewska and McDermott 2014) in their earlier comparison of FLEGT VPAs in Ghana and Indonesia, the relative balance of these authorities in different FLEGT VPA countries may impact dynamics of access. 
The following examination of VPAs in Ghana and Indonesia, conducted over a period of four years following the publication of (Lesniewska and McDermott 2014), will help to test the degree to which differences in the relative balance of authorities engaged in the Ghana and Indonesia VPAs have resulted in significant on-the-ground differences in forest access. To do this, we will review the general landscape of forest governance in each country, and then examine the governance impacts of VPA-related efforts.

\section{Methods}

This research was conducted between 2013 and 2018. It includes in-depth review of primary and secondary written material related to FLEGT and forest governance, as well as extensive field work conducted in Ghana and Indonesia. The field work which most directly informs this paper consists of semi-structured interviews on the FLEGT VPAs ${ }^{1}$ with over 70 government, large and small-scale industry, and NGO stakeholders, including 14 EU and UK respondents in 2015. The authors used purposive sampling to identify initial key informants, drawing on publicly available information on FLEGT stakeholders together with our professional networks. Initial informants were then asked to identify other key stakeholders through a process of snowball sampling.

The field work in Ghana occurred between 2013 and 2017, and was situated within an in-depth research project focused on six cocoa producing communities in the Assin South district of the

\footnotetext{
${ }^{1}$ As discussed later in this paper, the Indonesian FLEGT VPA is based on the Indonesian legality verification system "SVLK". Since most Indonesian stakeholders identified more strongly with the latter, where appropriate we tailored questions to Indonesian stakeholders around the SVLK rather than the FLEGT VPA.
} 
Central Region. This involved ethnographic fieldwork, 18 focus groups and 65 interviews over three years with key local actors including traditional authorities, cocoa farmers and chainsaw operators and small-scale timber millers. Four workshops were also conducted, two of which were held with national level stakeholders and two at a regional/district level. This broader research agenda provided important contextual knowledge on local forest governance and wood production. In addition, the material for this paper draws most directly on 28 in-depth semistructured interviews focused on the Ghana VPA, with government, traditional authorities, NGOs, industry associations, timber traders, and sawmillers.

In Indonesia, the authors carried out in depth interviews with 38 key informants at multiple scales who have been directly or indirectly involved in the policy processes of FLEGT VPA and the timber legality verification system (SVLK) in 2015 and follow up interviews in 2018. At the national level, in-depth semi structured interviews were carried out with government officers, nongovernmental organizations (NGOs), certifiers, researchers, and industry representatives, and at the international level, international NGOs, industry associations and donor agencies. The authors also conducted interviews with two heads of forest farmer associations from Java (APHR Magelang and Wonosobo); two representatives of forest farmer associations on Sumatra, including one who has obtained (GMWT) and one who has not obtained Verifikasi Legalitas Kayu/VLK certification (Gapoktan); a small-scale furniture producer (APKJ) and a representative of an Indonesian furniture industry and handicraft association (Asmindo).

This paper's analysis of primary and secondary written material includes the historical tracing of FLEGT VPA structures and VPA-related laws and policies in the EU, Indonesia and Ghana. This 
was situated within a broader analysis of the literature on global and EU international forest policy, and Indonesian and Ghanaian forest governance.

The semi-structured interviews were designed to complement this analysis with further information on how FLEGT VPAs were being implemented in law, policy and practice. The interviews were reviewed and coded to identify the perspectives, interests and actions of different stakeholders and whether and how they asserted power and authority to influence FLEGT VPA priorities. Special attention was placed on how respondents defined and operationalized good governance, and the degree to which it matched international conceptions of 'transparency', 'legibility' and external control, or recognition of local governance systems. The validity and reliability of the data collected was strengthened through triangulation of the results obtained through written sources, interviews and participant observation, and drawing on multiple informants to address similar questions. The authors conferred with each other before, during and after the analysis to ensure a common understanding of key concepts and themes.

\section{The 'internationalization' of access and control}

The core mechanism for implementing the FLEGT VPAs is the development of an internationally recognized timber legality licensing system, involving 'third party auditing' of legality (EC 2005). This approach is rooted in both the EU's state-based authority to regulate markets, and its trade-based authority as a significant consumer of tropical timber. This approach, which applies equally to Ghana, Indonesia, and all partner countries, is consistent with an ISO logic that pivots around the simplification and dis-embedding of rules and procedures from social context, reducing them to a set of auditable criteria that are transparent to external actors (Giddens 1990; Mutersbaugh 2005; Scott 1998). 
There are, however, some notable differences between Ghana and Indonesia in regards to the exercise of EU's state-based authority. The European Commission has assigned the Ghana VPA to the Directorate General (DG) for International Cooperation and Development, and the Indonesian VPA to DG Environment. This differential framing of VPA priorities, as either development or environmental protection, appears to match the alignment of international NGO interests. At the time of this research the two leading EU NGO organizations concerned with community rights under FLEGT focused more attention on Ghana than Indonesia. ${ }^{2}$ These different priorities for Ghana and Indonesia are also mirrored in the stakeholder dynamics within each country, as will be discussed in later sections of this paper.

Despite these differences, the international state and NGO stakeholders interviewed consistently emphasized the role of the VPAs in promoting international and national 'transparency'. For example, an interviewee from an EC representative emphasized: ${ }^{3}$

... the involvement of civil society ... in activities like independent monitoring, the transparency in terms of access to data and making publicly available information ... contribute to making also the domestic sector more transparent [to]national stakeholders....

Under this framing, communities are essentially watchdogs for legality. That is, they - along with national and international auditors - are internationalized as external actors who rely on

\footnotetext{
${ }^{2}$ Interviews, two key International NGO FLEGT stakeholders, 5/5/15; 12/7/16.

${ }^{3}$ Interview, European Commissioner, 07/09/15.
} 
standardized monitoring and reporting, and state authority, to gain knowledge of other actors (both local and non-local) and thereby assert control over them.

The prioritization of national scale authority, is likewise echoed in the following quote by a key EU NGO respondent: ${ }^{4}$

... what [FLEGT] did very well... NGOs and community-based organisations for the first time felt that they really had some power, and that they were really heard in national-level decision-making ...

The emphasis on national decision-making, with 'civil society' participation, appears to assume that such an alliance will also benefit local communities. The following country cases assess the validity of this assumption in the context of the Ghana and Indonesia VPAs.

\section{Ghana}

\section{Forest access in Ghana}

Since colonial times, Ghana's state-based legal system for managing lands and resources has focused on producing goods for export, from the expansion of agriculture and mining to the harvest of high value timber (Teye 2008). While customary authorities own most of the land in Ghana, native trees both on farms and in forest reserves are held in trust by the state. The Ghanaian Forestry Commission grants access to timber harvest both on and off reserves through

\footnotetext{
${ }^{4}$ Interview, international environmental NGO a, 12/07/15.
} 
a system of private timber concessions. The negotiation of access through the concession system is itself a complex process, which may involve political appointees and/or the use of ministerial decrees, transactions with high level traditional authorities and various other actors and avenues (Hirons et al 2018).

Timber concessionaires are legally required to obtain consent from traditional authorities and farmers before harvesting trees on farms, provide negotiated payments to local authorities and compensate farmers for damage to their cocoa trees. ${ }^{5}$ However in practice, local authorities and farmers vary considerably in their power to control concessionaire access and obtain compensation (Hansen 2011).

While the focus of state-based timber governance has been on exports, and local level actors have weak and very limited legal rights, rapidly rising urban and rural populations in Ghana have heightened domestic demand for timber. This rising domestic demand, together with deforestation for agriculture, the removal of high value timber for export to the EU and elsewhere, and growing demand for low value timber in other West African countries, has fuelled concerns over depletion of Ghana's timber resource (Hansen et al. 2012, Boakye 2015). In response, in 1998, around the time that illegal logging was beginning to become a focus of international attention, state-sanctioned local access to timber in Ghana was further reduced through a blanket ban on chainsaw milling. This criminalized thousands of chainsaw operators

\footnotetext{
${ }^{5}$ The compensation is legally restricted to cocoa trees, as opposed to other crops, although in practice it typically involves a standard cash payment irrespective of damage to the land and crops, e.g. see Hirons et al. 2018.
} 
overnight, as well as the majority of the domestic market reliant on chainsaw lumber. Current estimates suggest that $75 \%$ of the annual timber harvest in Ghana is used domestically or exported overland, and that $84 \%$ of the wood on the domestic market, most of which is produced by $\sim 100,000$ chainsaw operators, is illegal (Marfo and Acheampong 2011).

These high levels of 'illegality' in the domestic production and consumption are not necessarily characterised by a lack of legitimate authority. Customary norms vest timber ownership in land owners and farmers with locally recognized land-use rights (Lambrecht and Asare 2016). As one international environmental NGO interviewee noted: ${ }^{6}$

\section{"not a single tree in Ghana is cut without some form of social sanction (permission)."}

This is consistent with the findings of (Hirons et al. 2018), who observed that cocoa farmers in their study sites in Ghana's Central Region reported greater control over chainsaw operators than concessionaires. However, these local systems of control are not legible to larger scale actors. For example, a representative of the Domestic Lumber Timber Association (DOLTA), after discussing the shortage of legally available timber, reflected on the following: ${ }^{7}$

\footnotetext{
${ }^{6}$ Interview, international environmental NGO b, 28/05/15.

${ }^{7}$ Interview, domestic lumber association, 09/10/15.
} 
"You see... if we allow chainsaw to still continue to be exist, before we realise, you won't have anything left.... We don't even know the number of people who are doing the chainsaw. ... they are not under any kind of control..."

In contrast to local perceptions of greater control over chainsaw operators than government concessionaires, this national-scale industry actor claims it is the chainsaw operators who are illegible and out of control.

\section{The influence of the VPA on access}

Ghana began negotiations for a FLEGT VPA in 2007, reaching a signed agreement in 2009. A core requirement of the VPA is the creation of a 'legality standard' containing a bounded subset of Ghanaian law selected out of Ghana's larger legal framework, designed to be auditable by both Ghanaian authorities and international auditors (Ghana and EC 2009). In other words, the VPA follows an ISO-style model amenable to external surveillance. To facilitate this, Ghana is developing a Timber Legality Assurance Scheme and Wood Tracking System (TLAS/WTS) to verify that production has met the legality standard. This system is designed to meet EU requirements for issuing FLEGT licenses. The Forestry Commission has created a separate division, the Timber Validation Department as an independent body to oversee 'auditing' within the TLAS. The goal for the wood tracking system is to become completely digitized, with data that is fully standardized and accessible to all authorized parties.

The design of the TLAS thus involves an attempt to shift authority in Ghana's legal timber trade away from existing relational systems developed among political and public sector actors, traditional authorities, industry and local authorities, and to place it in the hands of international auditors and a new government department established to oversee the FLEGT licensing system. 
Consistent with the structure of legal wood production in Ghana, and the incentive structures of FLEGT, the design and testing of the TLAS scheme has focused on the minority of high value timber that is destined for export and produced from large-scale concessions. At the same time, it was nevertheless decided to include domestic timber in the TLAS.

Interviews with NGOs active in Ghana revealed mixed views on the inclusion of domestic timber in the VPA. For example, one Ghana-based NGO saw potential in the VPA to improve the power of communities to negotiate payments from timber companies harvesting trees on farms. ${ }^{8}$ In contrast, another Ghanaian NGO was critical of the idea of the VPA enforcing a legal system that gives external state actors control over access to trees on farms: ${ }^{9}$

“... you know, they nurtured that tree, the tree is there because of them, and yet they have to go seek permission to [cut] it"

A Forestry Commission respondent, who was generally very enthusiastic about the VPA, also commented on the potential livelihood impacts of eradicating illegality in the domestic sector: ${ }^{10}$

“... so many people are dependent on that kind of supply chain, illegal supply chain, so it's now an issue of livelihoods..."

\footnotetext{
${ }^{8}$ Interview, Ghanaian NGO d 08/10/15.

${ }^{9}$ Interview, Ghanaian NGO e, 07/10/15.

${ }^{10}$ Interview, Forestry Commission a, 06/10/15.
} 
Similarly, a representative of the Domestic Lumber Timber Association (DOLTA) noted that implementing the FLEGT VPA under current conditions could have dramatic effect on some producers and traders. As per the following quote from DOLTA: ${ }^{11}$

\section{"The market supply of timber from illegal sources is about $85 \%$.... And if ... you are going to implement VPA... what are we going to do about the ... shortfall? Where are we going to get the legal timber?"}

Consistent with this widespread awareness of the centrality of domestic markets to illegal logging, as well as to the importance of domestic markets to local economies, our stakeholder interviews uncovered a number of proposals currently being considered to address the issue. ${ }^{12}$ One proposal is based on a pilot project supported by international donors to develop a system of 'artisanal milling'. Under this system, licences would be granted to former chainsaw millers who have been retrained to operate bushmills, such as a Wood-mizer ${ }^{\mathrm{TM}}$, to process their wood for legal sale.

However, this would not tackle the problem of supplying timber to artisanal millers, since all concessions are currently already allocated to private companies. Several interviewees noted that the problem of supply might be addressed through an already existing ' $20 \%$ rule' on forest concessions. This rule, which to date is largely ineffective, requires all forest concessionaires to

\footnotetext{
${ }^{11}$ Interview, domestic lumber association, 09/10/15.

${ }^{12}$ See also (Hajjar 2015) for previous proposals. The focus of this paper is on the initiatives currently being discussed among stakeholder interviewees.
} 
deliver 20\% of their wood to the domestic market (Lund et al. 2012). According to interviewees, the timber allocated for this is low value and generally not suitable for export markets so contractors typically do not find it economical to remove it.

Yet there are at least a few fundamental problems with this approach. Assuming the $20 \%$ rule was effectively enforced, and $20 \%$ of the annual allowable cut was supplied to the domestic market regardless of price incentives, this would yield only 0.4 million cubic meters. This represents less than a third of the estimated 1.425 million cubic meters consumed by the domestic market annually. Furthermore, industry respondents expressed scepticism that concessionaires would allow artisanal millers access as it would create new liabilities for the primary concession-holder. ${ }^{13}$

Another challenge for artisanal millers, is that mills cost upwards of US\$25,000. We found already 15 (non-mobile) small-scale mills in the timber district covered by our field sites alone. It is difficult to imagine how many of the 97,000 chainsaw operators currently active throughout the country could afford to access such mills. This was also noted by the representative from DOLTA: ${ }^{14}$

'the idea is ... to employ the artisanal producers, a lot of these chainsaw people who will be redundant as a result of the VPA. But ... I don't think it will be able to do that. We already have a lot of these millers' associations, in every part of the country'.

\footnotetext{
${ }^{13}$ Interview, local sawmill, 02/10/15.

14 Ibid.
} 
In addition to artisanal milling, a Forestry Commission respondent highlighted a second proposal for legalizing domestic timber, intended to make domestic markets more lucrative. This is to establish a government procurement policy requiring that government agencies purchase only legally verified wood. However, while this might attract private companies to sell to domestic markets, it would do little to change the distribution of timber access. Given Ghana's legal framework, it is the existing timber concessionaires, not artisanal millers or local communities, who would be in the best position to capitalize on such markets.

A third proposal lies in the Forestry Commission's 2015-2040 plantation strategy, which outlines plans to rehabilitate the 397,000 ha of forest reserves (24\%) which have designated as converted or degraded (Ghana 2013). While such rehabilitation could contribute to supplying the domestic market, it would only do so in medium to long term (decadal timescales rather than annual). But more importantly, the strategy does not recognise that much of the degradation of reserves is due to the establishment of cocoa farms, and hence there is little 'idle' land to be had without displacement of poor farmers.

None of these strategies serve to effectively shift the sources of authority and legitimacy under FLEGT that currently favour state control and the access of large-scale industry and international actors to high value timber over customary systems of local control and access. Rather they align with the perspective that legality, and its presumed association to sustainability, can only be assured if all timber harvest is made legible, and hence controllable, at national and international scales.

None of the measures to address domestic timber promise incentives or compensation for the majority of local producers and domestic consumers whose already tenuous access to forest 
resources would be lost through effective implementation of the VPA. There have been attempts over many years to reform Ghana's tree tenure system to strengthen farmers' tree rights (e.g. Hajjar 2015), but proposals typically retain state control over harvest permits, and hence access to timber. A partial exception to this is a recent donor and private sector initiative for state registration of planted trees as a means to grant farmers rights and incentives to maintain trees on cocoa farms (UNDP 2016). However, we found no evidence that the VPA had driven this initiative, and it is unclear how millions of small farmers and the under-resourced Ghanaian state could significantly scale up this approach without wider legal reforms.

\section{Indonesia}

\section{Forest access in Indonesia}

Forest governance in Indonesia, as in Ghana, has historically focused on the extraction of valuable species for export, while domestic markets have developed through informal trade. State based resource extraction was consolidated under Suharto's regime in which the vast majority of the country's forest, most of which is unclassified or "un-gazetted" was declared as permanent forest estates controlled by the Ministry of Forestry (MoF). Within this estate, the MoF allocates timber through a system of timber concessions.

Since more than 91 percent of Indonesia's forest areas are still controlled and administered by the state (RRI 2013), the legal access of local communities to forest resources has been limited. Nevertheless, various studies have revealed a complex web of overlapping authorities governing access to forest resources, in which local and traditional rules are used to legitimize forest access 